\title{
Impact evaluation based on benefit indicators (IEBBI): methodological proposal for agroecological farmers' markets
}

\author{
Evaluación del impacto basada en indicadores de \\ beneficios (IEBBI): propuesta metodológica para \\ mercados de productores agroecológicos
}

David Perez-Castillo

a PhD in Administrative Sciences, Researcher, EGADE Business School, Tecnologico de Monterrey, Mexico City, Mexico E-mail: david.perez@tec.mx

doi:10.18472/SustDeb.v12n2.2021.36070

Received: 13/01/2021

Accepted: 09/06/2021 ARTICLE - VARIA

\begin{abstract}
Farmers' markets represent a growing strategy for the generation of food sovereignty and sustainability; however, little is known about their impacts in economic, social and environmental terms. The objective of this research was to develop a framework that would allow determining that impact. The resulting methodological framework includes 20 indicators divided into seven groups: proximity, profitability, perceived benefits, areas of opportunity, economic impact, social impact, and environmental impact. This methodology was applied in one agroecological farmers' market in Mexico City. Among the results, the main benefits are linked to socioeconomic interaction, while environmental impact indicators are the least considered. This methodology can guide the design, implementation, comparison, and monitoring of this type of initiative in the medium and long term.
\end{abstract}

Keywords: Farmers' markets. Organic markets. Short food chains. Impact assessment method. Agroecology. Socio-environmental project. Mexico.

\section{RESUMEN}

Los mercados de productores son una creciente estrategia de generación de soberanía alimentaria y sustentabilidad; sin embargo, poco se conoce de los impactos que han generado en términos sociales, ambientales y económicos. El objetivo de esta investigación fue desarrollar un marco analítico que permitiera determinar dicho impacto. El marco metodológico resultante está compuesto por 20 indicadores distribuidos en siete grupos: indicadores de proximidad, rentabilidad, beneficios percibidos, áreas de oportunidad, impacto económico, impacto social e impacto ambiental. Esta propuesta metodológica fue puesta a prueba en un mercado de productores agroecológicos de la Ciudad de México. Entre los resultados más sobresalientes sobre los datos descriptivos se pudo observar que los principales beneficios se encuentran en indicadores de interacción socioeconómica, mientras que los indicadores de impacto ambiental son los menos considerados. La metodología que se propone puede constituir una guía para orientar la política pública en el diseño, puesta en marcha, comparación y monitoreo de este tipo de iniciativas a mediano y largo plazo. 
Palabras Clave: Mercado de productores. Mercados orgánicos. Cadenas cortas agroalimentarias. Método para la evaluación de impacto. Agroecológico. Iniciativa socioambiental. México.

\section{INTRODUCTION}

Agroecological farmers' markets, also called "tianguis" or organic markets, have emerged as a response to different social, economic, and environmental factors, such as the exclusion of small producers, rising food prices, the ecological footprint, soil deterioration, concerns about healthy food, and others related to the sustainability of agri-food systems (STAGL, 2002). Agroecological farmer's markets are also one of several forms of short food marketing chains, among which are also direct sales in the production unit or outside it, urban agriculture, and self-consumption agriculture (SCHMUTZ et al., 2017). It is worth mentioning that agroecological markets differ from conventional markets in several aspects, some of which are shown in Table 1.

Table 1 | Differentiating characteristics between farmers' markets

\begin{tabular}{|c|c|c|}
\hline Differentiator & Conventional Markets & Agroecological Markets \\
\hline Objective & Satisfy food demand. & $\begin{array}{l}\text { Promote the consumption of agro- } \\
\text { ecological products and solidarity } \\
\text { economies. }\end{array}$ \\
\hline Participants & Traders or intermediaries. & $\begin{array}{l}\text { Direct producers and distributors, or } \\
\text { short supply chains. }\end{array}$ \\
\hline Products & Undifferentiated. & $\begin{array}{c}\text { Produced through agroecological } \\
\text { practices. }\end{array}$ \\
\hline Origin of products & $\begin{array}{l}\text { Not characterized, mostly from supply } \\
\text { centres. }\end{array}$ & $\begin{array}{c}\text { Generally local and to a lesser extent } \\
\text { national. }\end{array}$ \\
\hline Consumers & Undifferentiated. & $\begin{array}{l}\text { Consumers aware of the benefits of } \\
\text { agroecological products. }\end{array}$ \\
\hline Organization & Managed by local governments & $\begin{array}{l}\text { Self-organized by producers and/or by } \\
\text { NGOs. }\end{array}$ \\
\hline
\end{tabular}

Source: Own elaboration.

Since the late 1990s, more than 1,000 farmers' market initiatives have been reported in the USA (STAGL, 2002) and there are currently more than 8,700 (USDA, 2019). However, in Latin American countries their development has been much lower. For example, although in Mexico the first farmers' market (also called "tianguis", "tianguis orgánicos" or "tianguis agroecológicos" in the Mexican context) was formed in 1998 in Guadalajara (JIMÉNEZ CASTAÑEDA; BUSTAMANTE LARA, 2017), more than twenty years later there are only 40 initiatives (DOMINGUEZ, 2019) and there is no academic publication that proposes a scheme to determine and monitor their level of development.

Therefore, the objective of this research is to design and apply an impact evaluation framework for farmers' markets, which allows measuring the effect that farmers' markets generate concerning the benefits they offer under the Triple Bottom Line scheme (environmental, social, and economic) (ELKINGTON, 2004).

This paper presents a review of the academic literature on impact measurement in farmers' markets. Subsequently, the proposed Methodology of impact evaluation based on benefit indicators (IEBBI) is described. Next, the results of the application of this model in a farmers' market in Mexico City are presented. Finally, the results are discussed considering the implications for the promotion and development of farmers' markets in operational and public policy design aspects. 


\section{IMPACT ASSESSMENT ON FARMERS' MARKETS}

\subsection{IMPACT OBJECTIVES AND EXPECTED BENEFITS}

According to Gamboa Delgado and Rodríguez Ramírez (2015), the impact evaluation of a program or project "refers to the final attributable results and focuses on the outcomes or changes produced with respect to its objectives, over a period of time". The same author mentions that the main interest of impact evaluation consists in establishing the difference between the results obtained with the project and the results that could have been obtained if the project had not been implemented. Considering that the changes produced by an initiative are systemic and that their determination is complex, the impact evaluation of farmers' markets consists of determining the impact objectives of these initiatives, identifying the indicators that correlate with the impact objectives, and verifying that the measurement of the indicators is feasible.

The impact objectives of farmers' markets revolve around the effects of direct producer-consumer linkages. The principles proposed by FAO (2016) include minimum intermediation, process and product quality assurance (good agri-environmental and hygienic practices), proximity and transparency between producers and consumers, primary participation of small-scale agricultural producers, and collaborative consumers. From these principles derive a series of expected direct benefits such as reduced consumer prices, increased profitability, more nutritious or fresher products. Emerging benefits are also expected (ROGERS, 2008), such as the generation of trust between producers and consumers, co-creation of value, non-formal education of consumers. Examples of the main benefits and their relationship with the expected Sustainable Development Goals (SDG) can be seen in Table 2.

Table 2 | Relationship between impact objectives and expected benefits in producer markets.

\begin{tabular}{|c|c|c|}
\hline Impact objectives & Expected benefits & $S D G$ \\
\hline \multirow{2}{*}{ 1. Low intermediation } & Consumer price reduction & $\begin{array}{l}\text { 8. Decent Work and Economic } \\
\text { Growth }\end{array}$ \\
\hline & Producer profit increment & 10. Reduced inequalities \\
\hline 2. Quality assurance & $\begin{array}{l}\text { More nutritious products } \\
\text { Fresher products }\end{array}$ & 2. Zero hunger \\
\hline \multirow{3}{*}{ 3. Closeness and transparency } & Carbon footprint reduction & \multirow{3}{*}{ 4. Quality education } \\
\hline & Promotion of local culture & \\
\hline & Informal education & \\
\hline \multirow[b]{2}{*}{ 4. Small-scale producers } & Increased quality of life & \multirow[b]{2}{*}{ 3. Good health and well-being } \\
\hline & $\begin{array}{l}\text { Increased profitability of the } \\
\text { production unit }\end{array}$ & \\
\hline 5. Consumer's collaboration & $\begin{array}{l}\text { Co-creation of value } \\
\text { Greater bonding and support }\end{array}$ & 17. Partnerships for the goals \\
\hline
\end{tabular}

Source: Own elaboration.

\subsection{IDENTIFICATION OF INDICATORS AND IMPACT ASSESSMENT}

A search in Scopus using the terms 'farmers' market' found 462 documents, which coincides with the body of literature reported by Figueroa-Rodríguez et al. (2019). However, when searching within that body of literature for the term 'impact assessment', no results were found. Therefore, the search was expanded to any type of report on the effect of farmers' markets, which yielded 116 publications of which there were 27 books or book chapters, and 88 articles. A full-text review of each of the publications identified a total of 23 publications, which are described below. 
The identified literature began in 2002 with the work of Stagl (2002), although 10 articles were published in the last two years. In terms of origin, the majority (10) is based on the US experience, followed by the United Kingdom (6), and other countries such as Finland, China, Italy, Pakistan, Canada, New Zealand, and Spain (7). No publications from Latin American farmers' markets were identified. Most of these publications have used a mixed set of indicators (8), however, some have focused on economic (6), social interaction (5), environmental (2), and health (2) impacts.

The indicators that have been used in mixed evaluations have been very varied. Among them, we found articles where they make a distinction of social, economic, and environmental benefits, as in Schmutz et al. (2017) and Vittuari et al. (2017), but in others, they have focused on transportation reduction, the proximity of producers and consumers, impacts on farms, food equity, and human capital, among others. Eight articles were found that referred to impact assessment, but only one elaborated a comparative assessment (SCHMUTZ et al., 2017).

Economic indicators are the most frequently mentioned. We could classify them as benefits to the producer (ALI et al., 2017; JABLONSKI et al., 2016; SILVA et al., 2015), to the population (ALI et al., 2017; BECOT et al., 2018; THATCHER; SHARP, 2008), and in-market aspects (LARSEN; GILLILAND, 2009; MALAGON-ZALDUA; BEGIRISTAIN-ZUBILLAGA; ONEDERRA-ARAMENDI, 2018).

Social-type indicators refer to rootedness and integration (CHEN; SCOTT, 2014; ROY et al., 2017), but parameters such as historical context, civic activities, external supports, and social responsibility have also been addressed.

There is also a wide variety of indicators used in environmental matters. Among them are those linked to the productive unit, such as ecosystem services and soil erosion (HALE et al., 2014), and the environment in general, such as greenhouse gases and climate change (LARSEN; GILLILAND, 2009).

Finally, health-related indicators were regarding food sanitation (WRIGHT et al., 2015) and consumption of healthy products (JILCOTT PITTS et al., 2016). Although, as mentioned above, impacts on specific ailments have been analyzed.

\subsection{EVALUATION METHODS}

As mentioned above, no methods were identified for assessing the impacts of farmers' markets in a comprehensive manner; however, methods were found for certain elements. For example, the Rapid Assessment Market (RAM) developed by Lev et al. (2007) is based on an active research model to assess consumer perception. The Sticky Economic Evaluation Device (Seed) model developed by the MarketUmbrella (2005) and, according to Brown and Miller (2008), assesses supplier gross sales, external impact (consumer spending surveys), and anecdotal impact (interviews with shoppers, neighbours and community members). Another model was proposed by Schmutz et al. (2017), which is based on a participatory method and through which sustainability was evaluated in economic, environmental, and social terms by comparing five different models of short food supply chains (SFSCs) which were self-consumption urban agriculture, commercial urban agriculture, community-supported agriculture (CSA), direct sales in the production unit and direct sales outside the production unit.

On the economic side, the use of specific methods has been reported. The LM3 method is used to measure the local economic benefit of short marketing chains (THATCHER; SHARP, 2008). The Seed method, mentioned above, has been complemented with the Need (Neighborhood Exchange Evaluation Device) and Feed (Food Environment Evaluation Device) methods to assess the economic impact (MALAGON-ZALDUA et al., 2018). Input-output (IO) models have also been used to assess how public programs and policies that facilitate increased access to local food for low-income households can ripple through state economies (BECOT et al., 2018). 


\section{METHODOLOGICAL PROPOSAL}

\subsection{IEBBI MODEL}

Following the review of the evaluation frameworks available for short supply chains, it was observed that no model would allow impact evaluation under Latin American conditions. Therefore, a proposal was made for variables that could be evaluated through the perception of producers as objectively as possible, and this was defined as Impact Evaluation Based on Benefit Indicators (IEBBI). This proposal includes variables related to proximity, profitability, qualitative benefits, as well as social, economic and environmental impacts. These indicators are summarized in Table 3 and described below.

Proximity indicators. One of the main characteristics that promote short marketing circuits is the increase in proximity between the producer and the consumer (REINA-USUGA et al., 2018). In this sense, three indicators are considered: physical proximity between the place of production and the point of sale; commercial intermediation and social proximity. Both physical distance and social distance have been important elements of the drive for local markets, given that such distance is a factor in consumer alienation (RISKU-NORJA et al., 2008) and negative environmental impact (KEMP et al., 2010). Commercial intermediation is defined as the number of intermediaries or the number of instances that receive an economic benefit from marketing the product other than the one that carries out the production or manufacture. Social proximity is measured by the consumer's knowledge of the production unit and the activity with frequent customers.

Table 3 | Impact Evaluation Based on Benefit Indicators (IEBBI)

\begin{tabular}{ccc}
\hline Type & \multicolumn{1}{c}{ Indicator } & Measurement \\
\hline Proximity indicators & Physical proximity & $\begin{array}{l}\text { Distance between the place of production } \\
\text { and the point of sale. }\end{array}$ \\
Commercial intermediation & Number of intermediaries. \\
Profitability indicators & Social proximity & Closeness in the commercial relationship. \\
\hline
\end{tabular}

Proportion of the income Income from sustainable production.

$\begin{array}{cl}\text { Satisfaction } & \begin{array}{l}\text { Degree to which the producer is satisfied } \\ \text { with the productive activity and the } \\ \text { benefits received. }\end{array} \\ \text { Future investment } & \begin{array}{l}\text { Level of interest shown to invest in } \\ \text { productive activity. }\end{array} \\ \text { Production } & \begin{array}{l}\text { Improvements in production and / or } \\ \text { transformation }\end{array}\end{array}$

Commercialization Improvements in merchandizing

Indicators of perceived benefits

Income Benefits in the generation and stability of income 


\begin{tabular}{|c|c|c|}
\hline Type & Indicator & Measurement \\
\hline \multirow[t]{3}{*}{ Indicators of areas of opportunity } & $\begin{array}{l}\text { Barriers to entry for } \\
\text { producers }\end{array}$ & Difficulties attending the market. \\
\hline & $\begin{array}{l}\text { Barriers to entry for } \\
\text { consumers }\end{array}$ & Difficulty buying. \\
\hline & Improvement areas & Limitations to participate and grow. \\
\hline \multirow[t]{3}{*}{ Economic impact indicators } & Income & $\begin{array}{l}\text { Amount of income generated by } \\
\text { sustainable productive activity. }\end{array}$ \\
\hline & Employment & Number of jobs created. \\
\hline & Qualitative impacts & Other positive effects difficult to quantify. \\
\hline \multirow[t]{2}{*}{ Social impact indicators } & Collective & $\begin{array}{l}\text { Benefits of networking with other } \\
\text { producers. }\end{array}$ \\
\hline & Social contributions & $\begin{array}{l}\text { Sociocultural characteristics of productive } \\
\text { activity }\end{array}$ \\
\hline \multirow[t]{2}{*}{ Environmental impact indicators } & Agroecological production & $\begin{array}{l}\text { Characteristics of the product and raw } \\
\text { material. }\end{array}$ \\
\hline & Environmental contributions & $\begin{array}{l}\text { Environmental contributions of the } \\
\text { enterprise. }\end{array}$ \\
\hline
\end{tabular}

Source: Own elaboration.

Profitability indicators. Profitability in a small-scale production unit is difficult to determine since it is common for small producers not to keep records and labour costs are not considered since it is a family business, to mention a few. Therefore, indicators of employment generation, proportion of income, satisfaction, and future investment are used, according to the perception of the producers. Similar to the intention of Schmutz et al. (2017) to measure long-term profitability.

Indicators of perceived benefits. Belonging to a farmers' market for more than one year has generated different benefits for producers. Those related to improvements in production or processing, marketing, and income variation or stability are explored. These variables could be considered within the economic impact indicators; however, the measurement is not based on the economic data, but on the perception itself.

Indicators of areas of opportunity. To investigate the areas where the proposal and operation of the farmers' market can be improved, questions aimed at identifying the barriers to entry for producers, the respective barriers for consumers and the areas for improvement according to the perception of the beneficiaries are included, since it is common for sustainable ventures to present barriers such as scepticism, and lack of knowledge, among others (BINDER, 2016). Likewise, the perception of producers is investigated to achieve a successful farmers' market.

Economic impact indicators. The amount of income generated, employment generation, and qualitative impacts according to the perception of the producers are considered. 
Social impact indicators. Two indicators are evaluated: those derived from the linkage between producers and the social impacts of the venture, beyond those generated by the economic activity, such as philanthropic initiatives, cultural promotion, conservation of cultural capital, education, among others.

Environmental impact indicators. These include impacts generated directly by the agroecological method of production, which are the most widely reported in the literature (HALE et al., 2014; RISKU-NORJA et al., 2008; SIMONCINI, 2015), including ecosystem services and biodiversity. In addition, there are other contributions of the business model or form of production that present environmental benefits, such as the reduction of waste, the use of alternative energies, environmental education activities, among others.

\subsection{DESIGN OF THE INSTRUMENT}

Once the areas of evaluation were defined, in-depth interviews were conducted with producers to review the possibility that the variable could be measured, that the item could be understood, and that other relevant aspects to be considered were identified. Four in-depth interviews were conducted in November 2020.

The data collection instrument consists of a mixed questionnaire (37 closed-ended questions and 16 open-ended questions), with a total of 51 items, including 7 control items. The items are distributed to meet the standards of a self-administered questionnaire design (SCHWARZ, 2001).

\section{RESULTS OF THE APPLICATION OF THE IEBBI MODEL IN A CASE STUDY}

\subsection{POPULATION AND SAMPLING}

The population chosen for the case study was the "Producers' Market" of Mexico City (MP), which began activities in August 2017, promoted by the Mexico office of the Food and Agriculture Organization of the United Nations (FAO) and the Secretariat of Rural Development and Equity for Communities (Sederec). The objective of the MP is to "generate a meeting space between local producers and urban consumers committed to their health, the protection of the environment and the strengthening of local economies, under the principles of fair trade, Short Agrifood Chains (CCA) and without intermediaries" (FAO; SEDEREC, 2018).

However, due to the absence of producers, only 25 of the 34 registered producers (75\%) were able to participate. Nevertheless, according to the coordinators, those that participated are the most consistent. Two questionnaires were not fully completed because the participant did not have all the information because he/she was not responsible for the enterprise.

\subsection{PROFILE OF PRODUCERS' MARKET PARTICIPANTS}

Of the producers representing each project, 13 (54\%) are women and 11 are men. The age of the producers ranges from 26 to 64 years old. There is a particular concentration between 30 and 40 years of age, a range in which $30 \%$ of the producers are. However, 6 of them $(25 \%)$ are over 60 years old.

The main educational level among the group of producers is the university, which 14 of them have (58\%). Three representatives (13\%) have a postgraduate degree. Adding the producer representatives who have a bachelor's or postgraduate degree as their highest level of education gives a total of 17 producers, which represents $70 \%$. The distribution of men and women concerning educational level is very similar. 
Most of the farmers earn a family income of between 5 and 10 thousand Mexcian Pesos. Only two farmers generate incomes of more than 20,000 pesos per month. No significant statistical difference was found when comparing income concerning gender, age groups, the maximum level of education. Although it is observed that people with primary and secondary education earn less than 10 thousand pesos. It was observed that 18 enterprises $(78 \%)$ are family types and $5(22 \%)$ are group initiatives. The majority $(12,52 \%)$ of the projects are between 3 and 10 years old, 4 projects are two years old or less and only 2 projects are more than 20 years old.

\subsection{PROXIMITY INDICATORS}

Physical proximity. All production units of the MP participants were found within a perimeter of fewer than $30 \mathrm{~km}$. The average travel distance was $21 \mathrm{~km}$ ( $8.2 \mathrm{~min}$ and 32.5 max.) and 36 minutes (15 min and 63 max.) without considering vehicular traffic (Figure 1). However, 14 producers mentioned that given the traffic conditions it took them between 1 and 3 hours to reach the point of sale. Three producers obtain inputs from other states such as Veracruz, Oaxaca, and Querétaro.

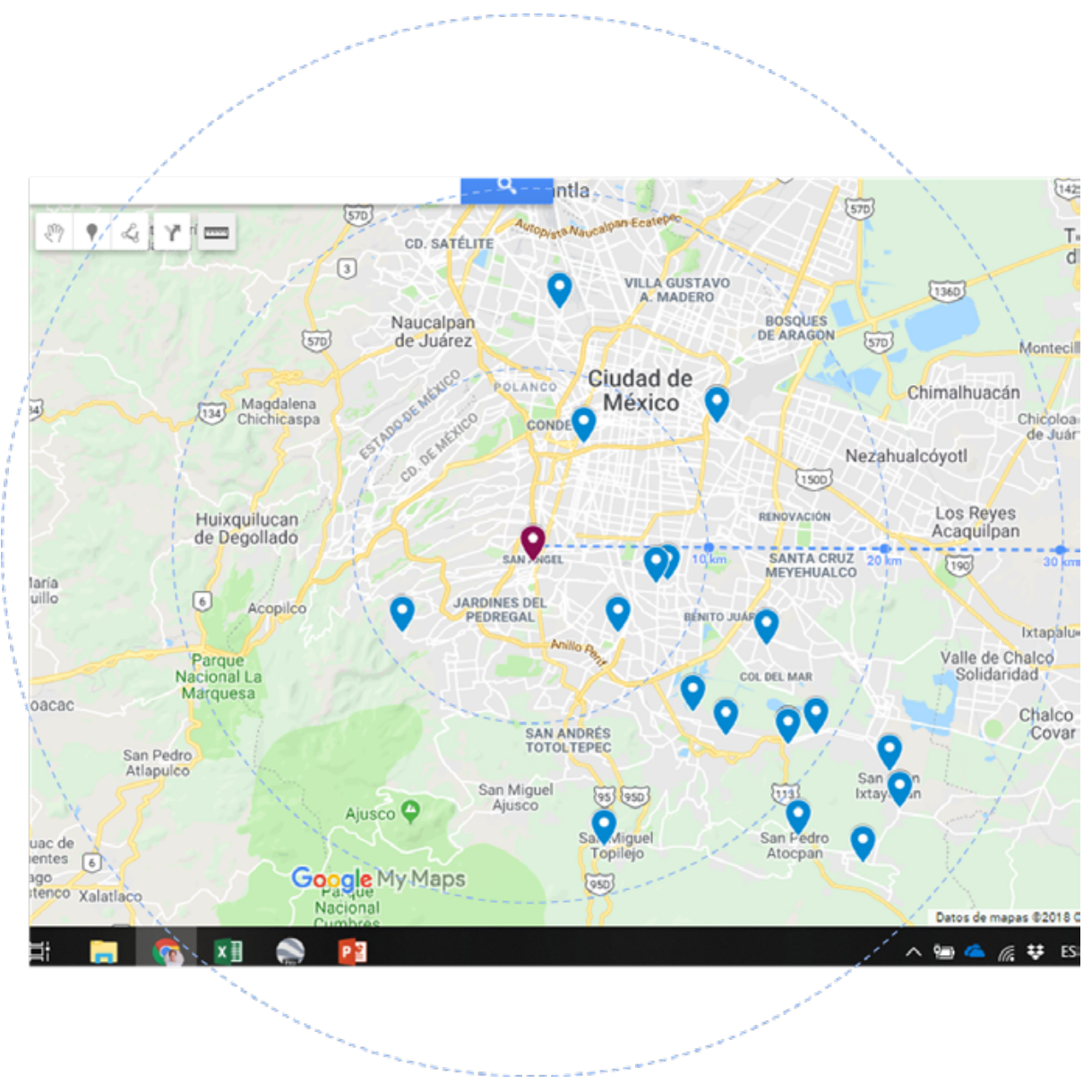

Figure 1 | The physical proximity of producers.

Source: Own elaboration with Google Maps technology.

Commercial intermediation. Producers have direct sales (70 points of sale); however, they also have a larger number of indirect sales (87 points of sale). Indirect sales outlets are mostly speciality stores and restaurants. The main source of income (more than $50 \%$ of income) for 11 producers comes from sales in the MP. For 4 of them, it represents $90 \%$ of income or more. On average, $80 \%$ of sales are made directly to the consumer. The remaining $20 \%$ is made indirectly (specialized stores $24 \%$, hotels, restaurants, etc. $18 \%$, intermediaries $19 \%$ and others 19\%) (Figure 2). 


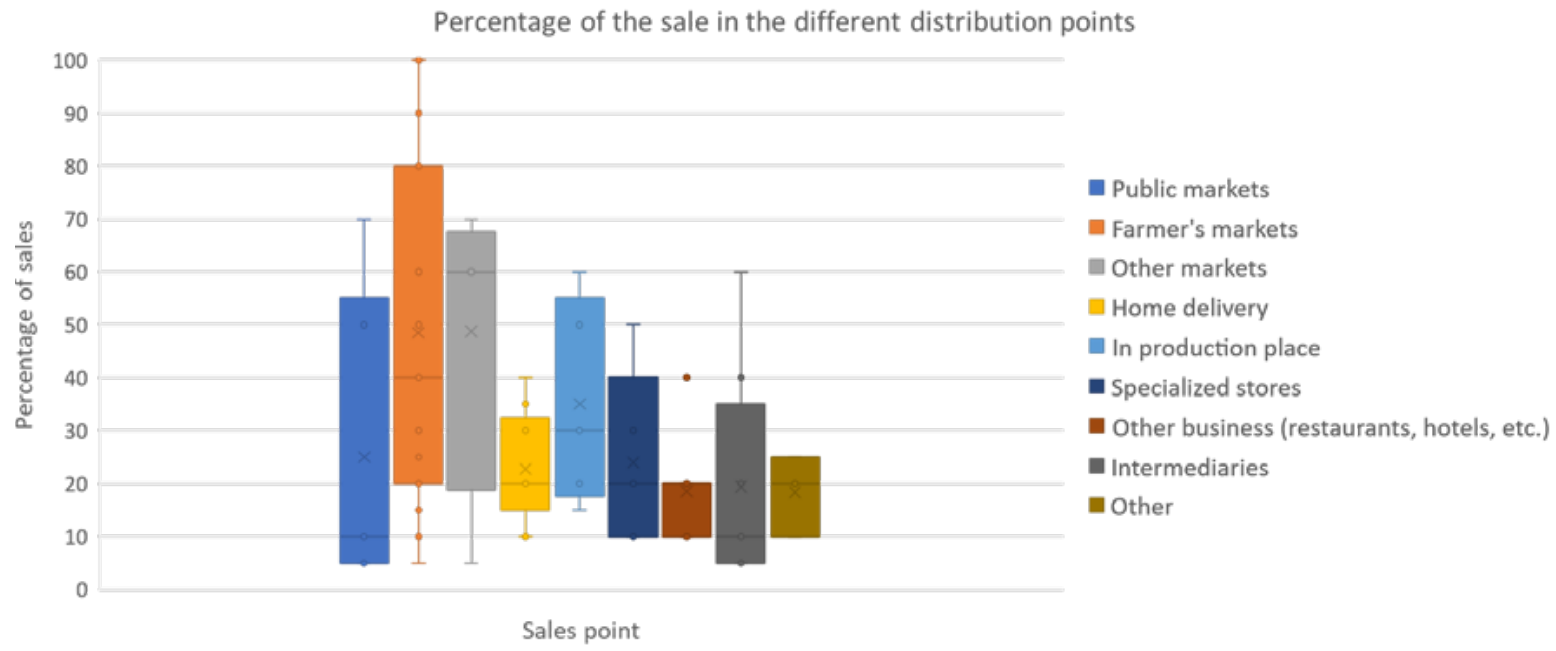

Figure 2 | Commercial intermediation.

Source: Own elaboration.

Social proximity. When asked about how many clients know the production unit and how many are interested in the producer, there was no clear trend (Figure 3.a and 3.b). The number of frequent clients per producer is between 11 and 20. nine producers mentioned that more than $15 \%$ of their sales comes from frequent clients (Figure 3.c). As for advance purchases, only 3 producers mentioned that more than 10 clients do so (Figure 3.d).

a) Customers who know the production unit

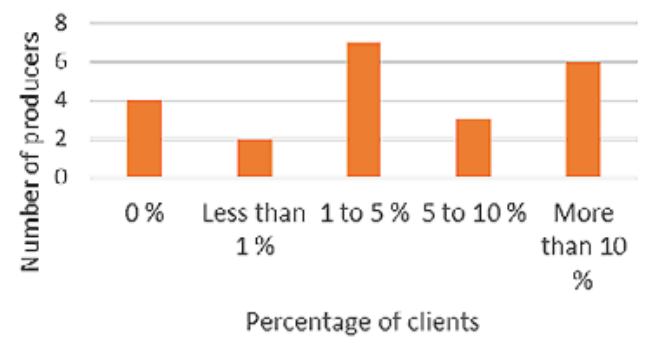

c) Number of frequent customers

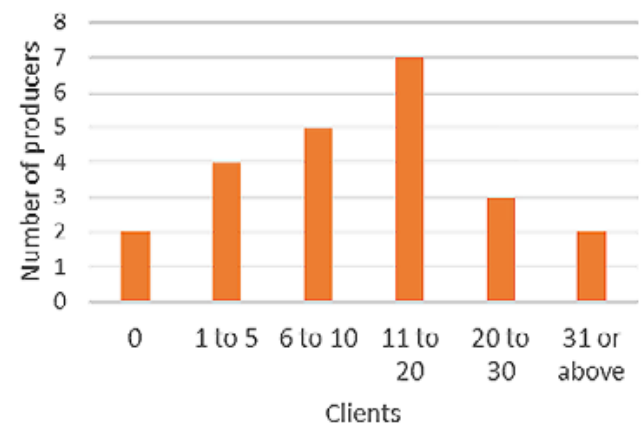

b) Clients interested in the producer

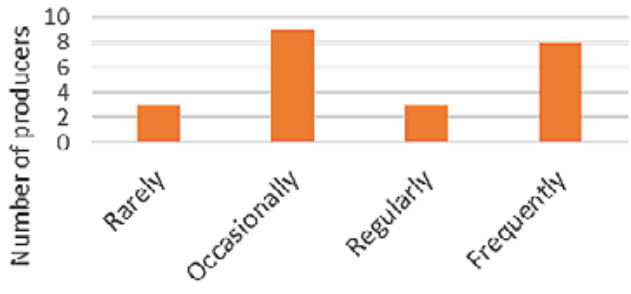

Frequency

d) Sales to frequent customers

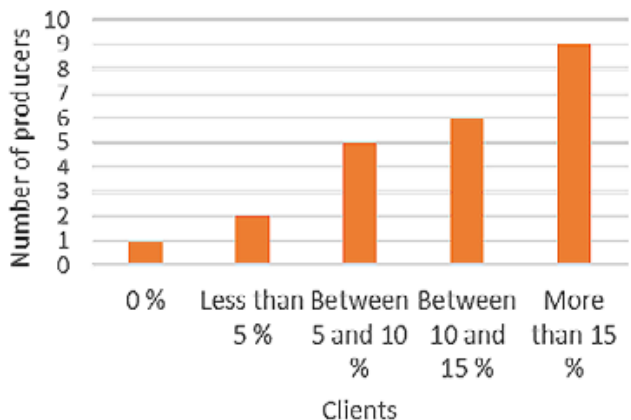

Figure 3 | Social proximity

Source: Own elaboration 


\subsection{PROFITABILITY INDICATORS}

Employment generation. Participants in the Producers' Market generate 120 jobs, 70 are permanent and 50 are casual. Most of the jobs are generated by personal or family enterprises. Collective ventures have been founded for a shorter period. On average, each venture generates 3 permanent jobs, including its founders. Some ventures generate more than 10 casual jobs (Figure 4.a).

Proportion of income. Ten producers depend solely on sales of agroecological or sustainable products. Six producers depend less than $40 \%$ of their income on sustainable production. The majority ( 9 producers) earn between 5 and 10 thousand pesos and 9 producers generate 20 thousand pesos or more monthly (Figure 4.b).

Degree of satisfaction. Eight producers mentioned that they are close to reaching the desired sales volume. Fifteen producers mentioned being far from the desired level of sales. The benefits they obtain from productive activity, in addition to the economic one, were: having contact with clients (8), promoting or having a good quality of life (7), family integration and economic independence (2) and personal development (1) (Figure 4.c).

Investment required. Eleven producers mentioned that to continue developing their project they require an investment fewer than 30 thousand pesos and twelve require a larger investment. Most of the needs focused on machinery, tools and materials for marketing. The options that were not selected are wages, salaries and payments for services (Figure 4.d).

Projection to success. The answers to the question "What does it take to be successful?" revolved around aspects related to business development (dissemination, labelling, logistics, etc.), rather than productive aspects (inputs, production training, machinery, and tools).
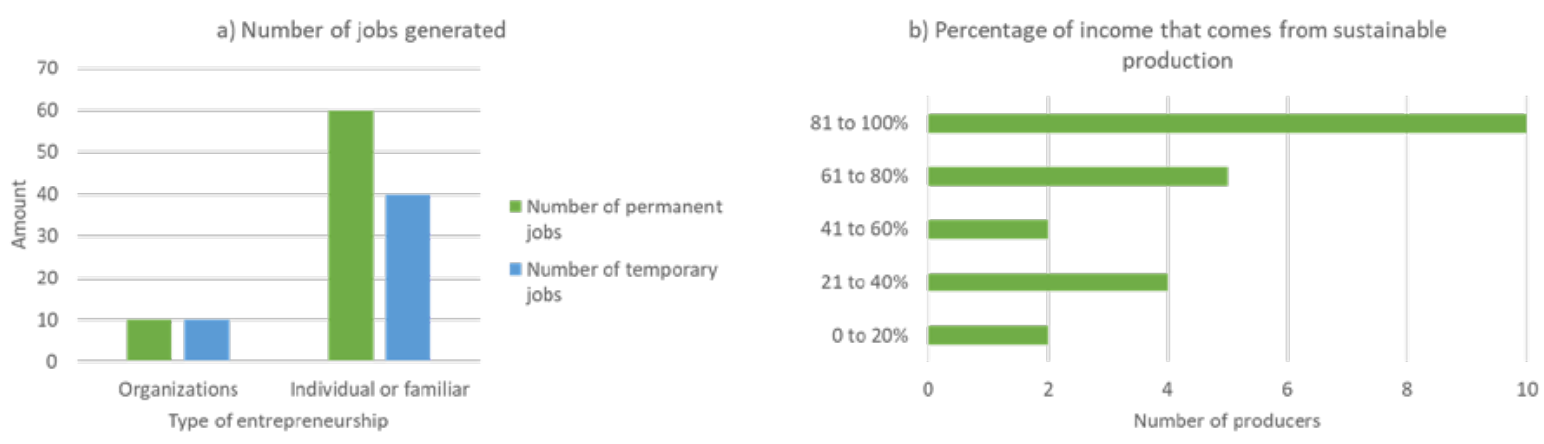

c) From 1 to 10 , how close are you to reaching your desired sales level?
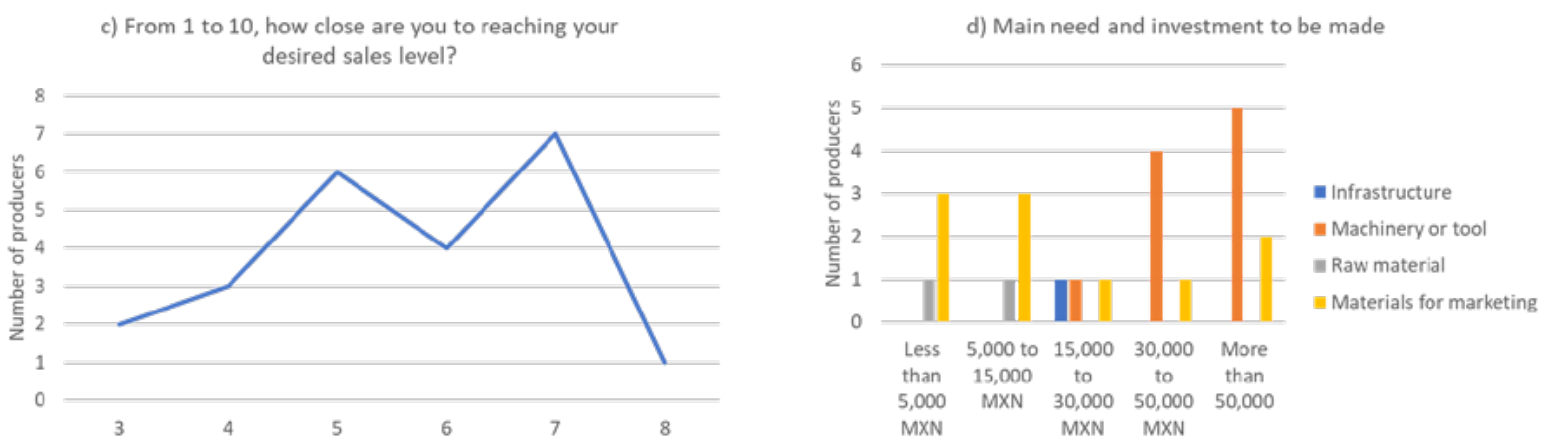

Figure 4 | Profitability indicators 


\subsection{INDICATORS OF PERCEIVED BENEFITS}

Production benefits. The main benefits in production were presented in the increment in the quantity produced, the improvement of the product's image and the increment in production know-how. The options referring to improvements in production processes and costs were not selected (Figure 5.a).

Marketing benefits. When asked about the main marketing improvement, producers mentioned that they have had better direct access to customers, an increased number of customers, and increased channels for distribution. Improved sales skills and reduced marketing costs were not selected (Figure 5.b).

Additional benefits. Most of the perceived benefit is focused on improved revenue stability. However, improvements in increased revenue and increased customers are similar. The least perceived benefit was observed in the improved unit price of products (Figure 5.c).
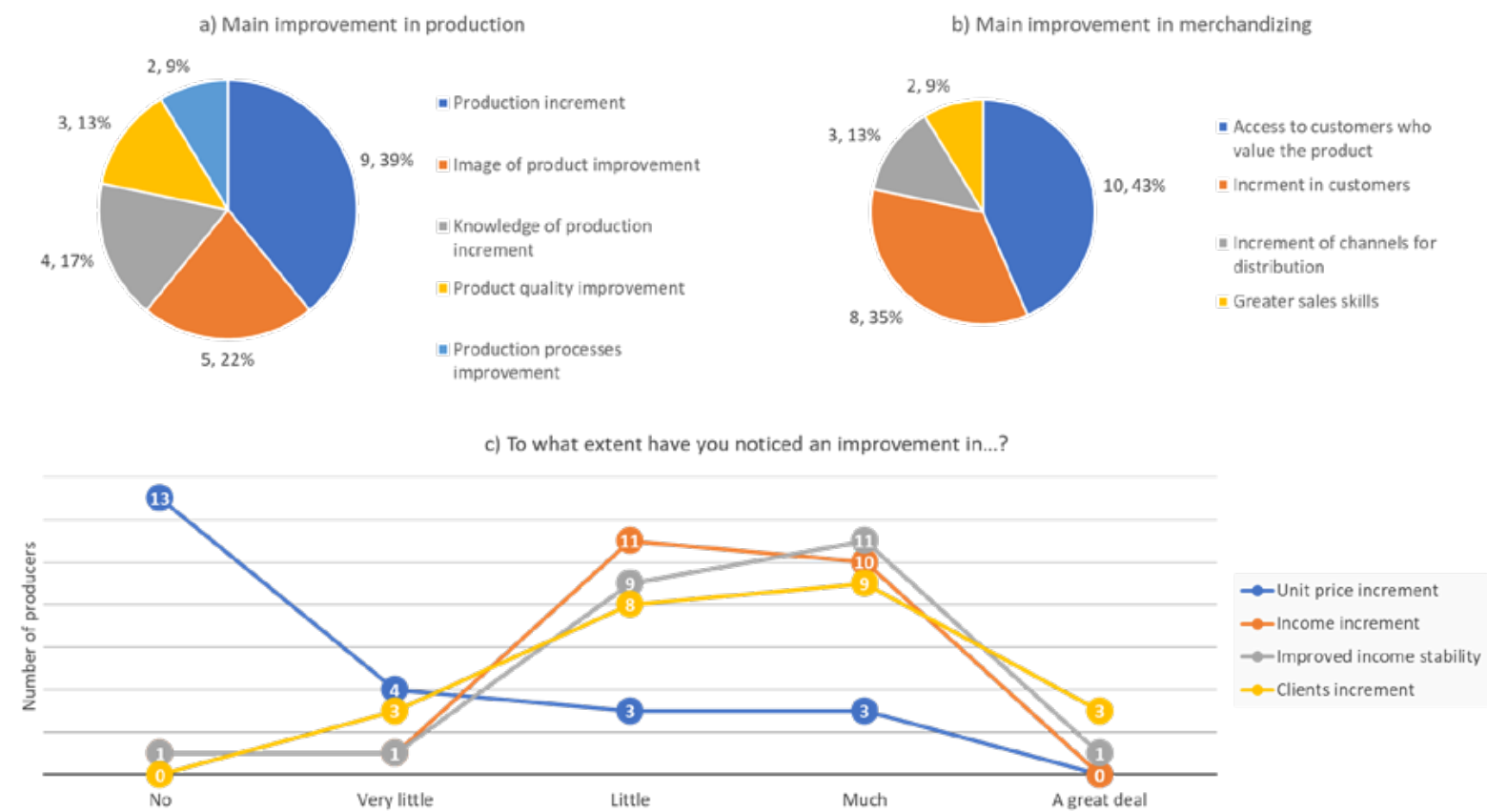

Figure 5 | Indicators of perceived benefits

Source: Own elaboration

\subsection{INDICATORS OF AREAS OF OPPORTUNITY}

Limitations to producer participation. The main barrier to entry reported is lack of transportation (52\%), followed by lack of product quality (19\%), too little income generated in the market (14\%), lack of time $(10 \%)$, and poor personal relationships with other members (5\%).

Limitations to consumer participation. Sixty-one per cent of the producers said that the main barrier for consumers to attend was that they were not aware of the existence of the market, followed by lack of socio-environmental awareness (22\%), distance from home (9\%), lack of variety $(4 \%)$, and lack of time to go to the market (4\%). The only option not selected was the high prices compared to the conventional product. 
Success factors of a PM. According to the producers, the main elements of success are dissemination, a fixed location, and the quality of the products. The honesty and participation of the producers and the leadership of the coordination were also mentioned.

\subsection{ECONOMIC IMPACT INDICATORS}

Income. Although the source of income of many of the farmers varies, the majority of the main source of income comes from the sale of agroecological or sustainable products. Of the 10 producers most dependent on the sale of these products, 2 generate less than 5 thousand pesos, one earns between 5 , and 10 thousand pesos, one earns between 10 and 20 thousand pesos, 6 generate income of 20 thousand pesos or more per month.

Qualitative impacts. When producers were asked about other economic benefits, the responses revolved around facilitating linkages with clients (43\%) and higher sales volumes (39\%); the options of better income and higher sales occupied only $18 \%$.

\subsection{SOCIAL IMPACT INDICATORS}

Guild participation. The main benefit of social interaction (22\%), which could well be a commercial benefit, is that 5 producers exchange products among themselves for processing. The second perceived benefit is that other producers recommend the product (22\%). Also, a similar number of producers mention that they have learned from other producers $(22 \%)$ and that they are motivated by other producers $(19 \%)$.

Social contribution. Most of the projects (15) have impacts related to the conservation of a cultural or traditional element, 9 projects benefit low-income people and 6 promote education for children (Table 4). None has records of such activities.

Table 4 | Social contribution

\begin{tabular}{|c|c|c|c|}
\hline Impact & Groups or organizations & Individual or familiar & Total \\
\hline $\begin{array}{l}\text { Rescue or conservation of a local } \\
\text { cultural or traditional product }\end{array}$ & 5 & 10 & 15 \\
\hline $\begin{array}{l}\text { Production in which low-income } \\
\text { producers get benefits }\end{array}$ & 2 & 7 & 9 \\
\hline $\begin{array}{l}\text { Inclusive project of women, with different } \\
\text { capacities and other minorities }\end{array}$ & 1 & 3 & 4 \\
\hline $\begin{array}{l}\text { Promotion of education in children } \\
\text { (not environmental) }\end{array}$ & & 5 & 5 \\
\hline Promotion of adult training & & 3 & 3 \\
\hline
\end{tabular}

Source: Own elaboration

\subsection{ENVIRONMENTAL IMPACT INDICATORS}

Agroecological production and supply. 21 producers process raw material directly. Only two producers obtain the raw material from conventional production, and this is because they have not found the agroecological option. Some producers have only one product, but some producers have more than 100 different products and presentations (Table 5). 
Table 5 | Agroecological production

\begin{tabular}{|c|c|c|c|c|}
\hline Offer & $\begin{array}{l}\text { All products are made } \\
\text { from primary } \\
\text { production }\end{array}$ & $\begin{array}{l}\text { For some products, } \\
\text { we buy supplies from } \\
\text { agroecological } \\
\text { producers }\end{array}$ & $\begin{array}{l}\text { For most of the pro- } \\
\text { ducts we buy supplies } \\
\text { from other } \\
\text { agroecological } \\
\text { producers }\end{array}$ & $\begin{array}{l}\text { Most of the supplies } \\
\text { come from conventional } \\
\text { production }\end{array}$ \\
\hline Fresh food & 5 & 5 & & \\
\hline Processed foods & 8 & 5 & 7 & \\
\hline Prepared food & & 2 & & \\
\hline Arts or crafts & 1 & & & \\
\hline $\begin{array}{l}\text { For personal and home } \\
\text { cleaning }\end{array}$ & & 1 & & 1 \\
\hline Medicinal products & 2 & & & 1 \\
\hline $\begin{array}{l}\text { Supplies for agricultural or } \\
\text { livestock production }\end{array}$ & 1 & & & \\
\hline $\begin{array}{l}\text { Educational or training } \\
\text { products }\end{array}$ & 4 & 1 & & \\
\hline Ornamental plants & & & 1 & \\
\hline
\end{tabular}

Source: Own elaboration

Environmental contribution. Most of the projects (15) mentioned having impacts related to agroecological production: 4 projects have organic certification and 7 have other types of certification. Likewise, 7 projects carry out biodiversity conservation and 9 carry out pre-designed environmental education activities (Table 6). However, none of them quantifies impacts.

Table 6 | Environmental contribution

\begin{tabular}{cccc}
\hline Impact & $\begin{array}{c}\text { Groups or } \\
\text { organizations }\end{array}$ & $\begin{array}{c}\text { Individual } \\
\text { or familiar }\end{array}$ & Total \\
\hline Certified organic & 1 & 3 & 4 \\
Some other types of certification & 1 & 6 & 7 \\
Agroecological or natural & 2 & 13 & 15 \\
Zero waste generation & 1 & 5 & 6 \\
Soil restoration & & 6 & 5 \\
Water collection and recycling & 1 & 4 & 1 \\
Carbon sequestration & & 1 & 4 \\
Zero greenhouse gas emissions & 1 & 3 & 3 \\
Use of solar or wind energy & & 3 & 7 \\
\hline Conservation of biodiversity of plants or animals & 1 & 6 & 9 \\
\hline
\end{tabular}




\section{DISCUSSION}

\subsection{RELEVANCE OF BENEFIT-BASED ASSESSMENT}

In this article, rather than discussing the results obtained in this particular market, what is sought is to discuss the methodology employed. After the design work, several indicators were left out and may be important, such as those related to sanitation or health.

One of the main observations is regarding the relevance of the non-quantitative benefits that producers have had. After more than two years of operation, several of the producers mentioned that although the income and stability had improved a little, they was not what most motivated them to continue attending, since as identified by Charatsari et al. (2018) there are psychological or social factors that motivate participation. The aspect of having the opportunity to raise consumer awareness proved to be important. In this sense, evaluation elements should be oriented to social capital aspects. Environmental education activities can be one of these elements since, as studied by Schmit et al. (2017), such activities have an effect of increasing the flow of intellectual capital.

Another relevant indicator is the benefits that producers generate by linking and collaborating. In this research, it was observed that the linkage has allowed them to share client portfolios, give each other production recommendations and exchange products, and to a lesser extent, help each other overcome daily complications and give each other marketing recommendations. It has already been reported in the literature that farmers' markets can be a strategy for increasing social capital linked to food production (VOLPENTESTA; AMMIRATO; DELLA GALA, 2013). However, it seems that public promotion policies do not consider this element, most likely because of their difficulty of evaluation. In other words, limiting the evaluation of farmers' markets to economic aspects is a short-sighted view of the range of benefits.

It is important to discuss whether the direct linkage of the producer to the consumer provides increased social proximity. During this research, it is perceived that, despite physical proximity, social proximity in this market was low. This leads us to visualize that farmers' markets can have two different configurations. The first is where there is high social proximity, most likely derived from citizen management in which there is direct communication between producers and consumers as well as risk-sharing as mentioned by Stagl (2002) called community-supported agriculture (CSA). Secondly, there are initiatives in which there is no strong link between the producer and the consumer. As Chen and Scott (2014) demonstrated for consumer rootedness, social proximity can be an essential element of the success of a farmers' market, both in its growth and its permanence, and it is something that the promoters of these initiatives and public policy designers should consider. That is, thinking that generating a farmers' market consists only of convening producers and managing spaces, without considering citizen ownership (O'HARA; COLEMAN, 2017), can lead to these initiatives not acquiring sufficient strength, collapsing when external support runs out.

Another important aspect is that, even though producers observe that their activity has benefits for the environment, the consumer and for themselves, they do not have records that allow them to evidence them. This is particularly relevant concerning the promotion of farmers' markets. One of the main key factors of markets is the location (MORCKEL, 2018), and at least in Mexico, the availability of opening new spaces is limited since the opinion of officials and regulations do not allow new commercial spaces to be opened and less in areas with high pedestrian traffic, even when it is about contributing to sustainability. Therefore, if new spaces are to be opened or current ones improved for producers' markets, the benefits must be quantified and monitored, since, as mentioned by Ragona and Mazzocchi (2008), the lack of data makes it difficult to estimate the dynamics of regulation and the possibility of endogenous relationships, and therefore there are few elements to favour the creation of new markets. 


\subsection{LIMITATIONS AND FUTURE RESEARCH}

One of the limitations of this research is that the evaluation model was applied to only one market. Therefore, it is necessary to extend the application of the model to more units and in longitudinal studies. A second limitation is that, as mentioned in the literature, farmers' markets have had different conceptions and varying growth histories in different countries, so it is to be expected that the evaluation frameworks need to be adapted depending on cultural conditions.

\section{CONCLUSIONS}

The promotion of agroecological farmers' markets is an important strategy to promote the Sustainable Development Goals and it is necessary to generate tools to demonstrate their success. This research fulfils the objective of designing and implementing an evaluation model for farmers' markets from the farmers' perspective. The method was designed to be replicable in other farmers' markets. The application is quick since it is a questionnaire that would be applied once a year ( 20 minutes per participant) and the results are easy to process, although the necessary modifications can be made depending on the objectives of each country or region.

Evaluation metrics should consider indicators of physical and social proximity, profitability, perceived benefits, areas of opportunity, economic impact, social impact and environmental impact. Likewise, consumer and producer health metrics can be included, as well as product health. The only thing to consider is that the number of indicators added may increase the length of the instrument and generate fatigue in the participants, which is why a review should be made before its application.

It is important to emphasize that the promoters of this type of initiative should observe the desired impact indicators and based on this, establish operational improvements. This will support the relevance of promoting farmers' markets, since currently, despite the environmental problems, there have been few achievements in terms of generating farmers' markets in Mexico.

\section{ACKNOWLEDGEMENTS}

To the participants and organizers of the Producers' Market who collaborated in the realization of this research.

\section{REFERENCES}

ALI, A.; ABDULAI, A.; RAHUT, D. B. Farmers' Access to Markets: the case of cotton in Pakistan. Asian Economic Journal, v. 31, n. 2, p. 211-232, 2017. https://doi.org/10.1111/asej.12116

BECOT, F. A. et al. Can a shift in the purchase of local foods by Supplemental Nutrition Assistance Program (Snap) recipients impact the local economy? Renewable Agriculture and Food Systems. https://doi.org/10.1017/ S1742170518000327, 2018.

BINDER, J. K. Theorizing about sustainable entrepeneurship. Technische Universität München, 2016.

BROWN, C.; MILLER, S. The impacts of local markets: a review of research on farmers markets and community supported agriculture (CSA). American Journal of Agricultural Economics, v. 90, n. 5, p. 1296-1302, 2008. https:// doi.org/10.1111/j.1467-8276.2008.01220.x

CHARATSARI, C. et al. Antecedents of farmers' willingness to participate in short food supply chains. British Food Journal, v. 120, n. 10, p. 2317-2333, 2018. https://doi.org/10.1108/BFJ-09-2017-0537 
CHEN, W.; SCOTT, S. Shoppers' perceived embeddedness and its impact on purchasing behavior at an organic farmers' market. Appetite, v. 83, p. 57-62, 2014. https://doi.org/10.1016/j.appet.2014.08.010

DOMINGUEZ, C. Impulsan Mercados de Productores. Reforma. 2019. Available at: https://www.reforma. com/aplicacioneslibre/preacceso/articulo/default.aspx?id=1589147\&urlredirect=https://www.reforma.com/ aplicaciones/articulo/default.aspx?id=1589147. Accessed on: March 20, 2021.

ELKINGTON, J. Enter the Triple Bottom Line. In: HENRIQUES, A.; RICHARDSON, J. (ed.). The Triple Bottom Line, Does It All Add Up? Assessing the Sustainability of Business and CSR (p. 1-16). London, Ingland: Earthscan, 2004.

FAO. Memorias del taller de intercambio de experiencias en cadenas cortas agroalimentarias. Ciudad de México: Organización de las Naciones Unidas para la Alimentación y la Agricultura, 2016.

FAO; SEDEREC. Capital Verde. Mercado de Productores, 2018.

FIGUEROA-RODRÍGUEZ, K. A. et al. Farmers' market actors, dynamics, and attributes: a bibliometric study. Sustainability (Switzerland), v. 11, n. 3, 2019. https://doi.org/10.3390/su11030745

GAMBOA DELGADO, E. M.; RODRÍGUEZ RAMÍREZ, S. Consideraciones bioéticas en estudios experimentales de evaluación de impacto de programas. Revista de La Facultad de Medicina, v. 62, (1 Sup), p. 115-120, 2015. https://doi.org/10.15446/revfacmed.v62n3sup.40651

HALE, I. L. et al. A scale-explicit framework for conceptualizing the environmental impacts of agricultural land use changes. Sustainability (Switzerland), v. 6, n. 12, p. 8432-8451, 2014. https://doi.org/10.3390/su6128432

JABLONSKI, B. B. R.; SCHMIT, T. M.; KAY, D. Assessing the economic impacts of food hubs on regional economies: a framework that includes opportunity cost. Agricultural and Resource Economics Review, v. 45, n. 1, p. 143-172, 2016. https://doi.org/10.1017/age.2016.9

JILCOTT PITTS, S. B. et al. Assessing Preliminary Impact of the North Carolina Community Transformation Grant Project Farmers' Market Initiatives Among Rural Residents. Journal of Nutrition Education and Behavior, v. 48, n. 5, p. 343-349.e1, 2016. https://doi.org/10.1016/j.jneb.2016.03.001

JIMÉNEZ CASTAÑEDA, R.; BUSTAMANTE LARA, T. I. Mercados Orgánicos Y Su Probabilidad de Sostenibilidad a a Través de Tres Indicadores Teóricos. Pretium: revista de economía, finanzas y negocios, v. 7, n. 1, p. 1-8, 2017.

KEMP, K. et al. Food miles: do UK consumers actually care? Food Policy, v. 35, n. 6, p. 504-513, 2010. https://doi. org/10.1016/j.foodpol.2010.05.011

LARSEN, K.; GILLILAND, J. A farmers' market in a food desert: evaluating impacts on the price and availability of healthy food. Health and Place, v. 15, n. 4, p. 1158-1162, 2009. https://doi.org/10.1016/j.healthplace.2009.06.007

LEV, L.; STEPHENSON, G.; BREWER, L. Practical Research Methods to Enhance Farmers Markets. In: HINRICHS, C. C.; LYSON, T. A. (eds.). Remaking the North American Food System: strategies for sustainability, p. 84-98. Lincoln, NE: University of Nebraska Press, 2007.

MALAGON-ZALDUA, E.; BEGIRISTAIN-ZUBILLAGA, M.; ONEDERRA-ARAMENDI, A. Measuring the economic impact of farmers' markets on local economies in the basque country. Agriculture (Switzerland), v. 8, n. 1, p. 10, 2018. https://doi.org/10.3390/agriculture8010010

MARKETUMBRELLA. Sticky Economic Evaluation Device: an economic measurement tool for public markets. 2005. Available at: http://www.marketumbrella.org/seed. Accessed on: March 14, 2019.

MORCKEL, V. The direct economic impact of the Flint, Michigan, farmers' market relocation. Community Development, v. 49, n. 2, p. 161-174, 2018. https://doi.org/10.1080/15575330.2017.1418758

O'HARA, J. K.; COLEMAN, C. The impacts of the Farmers Market and Local Food Promotion programs. Community Development, v. 48, n. 5, p. 681-696, 2017. https://doi.org/10.1080/15575330.2017.1350729 
RAGONA, M.; MAZZOCCHI, M. Food safety regulation, economic impact assessment and quantitative methods. Innovation, v. 21, n. 2, p. 145-158, 2008. https://doi.org/10.1080/13511610802214511

REINA-USUGA, L.; DE-HARO, T.; PARRA-LÓPEZ, C. Territorial short food supply chains: conceptualization and characterization for the case of Córdoba, Spain. Itea - Informacion Tecnica Economica Agraria, v. 114, n. 2, p. 183-202, 2018. https://doi.org/10.12706/itea.2018.012

RISKU-NORJA, H. et al. Localisation of primary food production in Finland: production potential and environmental impacts of food consumption patterns. Agricultural and Food Science, v. 17, n. 2, p. 127-145, 2008. https://doi. org/10.2137/145960608785328233

ROGERS, P. J. Using Programme Theory to Evaluate Complicated and Complex Aspects of Interventions. Evaluation, v. 14, n. 1, p. 29-48, 2008. https://doi.org/10.1177/1356389007084674

ROY, H.; HALL, C. M.; BALLANTINE, P. Trust in local food networks: the role of trust among tourism stakeholders and their impacts in purchasing decisions. Journal of Destination Marketing and Management, v. 6, n. 4, p. 309317, 2017. https://doi.org/10.1016/j.jdmm.2017.07.002

SCHMIT, T. M. et al. Rural wealth creation of intellectual capital from urban local food system initiatives: developing indicators to assess change. Community Development, v. 48, n. 5, p. 639-656, 2017. https://doi.org/10.1080/15 575330.2017 .1354042

SCHMUTZ, U. et al. Sustainability impact assessments of different urban short food supply chains: examples from London, UK. Renewable Agriculture and Food Systems, v. 33, n. 6, p. 518-529, 2017. https://doi.org/10.1017/ S1742170517000564

SCHWARZ, N. Asking questions about behavior: cognition, communication, and questionnaire construction. The American Journal of Evaluation, v. 22, n. 2, p. 127-160, 2001. https://doi.org/10.1016/S1098-2140(01)00133-3

SILVA, E. et al. Impact of marketing channels on perceptions of quality of life and profitability for Wisconsin's organic vegetable farmers. Renewable Agriculture and Food Systems, v. 30, n. 5, p. 428-438, 2015. https://doi. org/10.1017/S1742170514000155

SIMONCINI, R. Introducing territorial and historical contexts and critical thresholds in the analysis of conservation of agro-biodiversity by alternative food networks, in Tuscany, Italy. Land Use Policy, v. 42, p. 355-366, 2015. https://doi.org/10.1016/j.landusepol.2014.08.010

STAGL, S. Local organic food markets: potentials and limitations for contributing to sustainable development. Empirica, v. 29, n. 2, p. 145-162, 2002. https://doi.org/10.1023/A:1015656400998

THATCHER, J.; SHARP, L. Measuring the local economic impact of National Health Service procurement in the UK: an evaluation of the cornwall food programme and LM3. Local Environment, v. 13, n. 3, p. 253-270, 2008. https:// doi.org/10.1080/13549830701669005

USDA. Local Food Directories: national farmers market directory. Available at: https://www.ams.usda.gov/localfood-directories/farmersmarkets, Accessed on: March 10, 2019.

VITTUARI, M.et al. The second life of food: an assessment of the social impact of food redistribution activities in Emilia Romagna, Italy. Sustainability (Switzerland), v. 9, n. 10. https://doi.org/10.3390/su9101817

VOLPENTESTA, A. P.; AMMIRATO, S.; DELLA GALA, M. Classifying short agrifood supply chains under a knowledge and social learning perspective. Rural Society, v. 22, n. 3, p. 217-229, 2013. https://doi.org/10.5172/rsj.2013.22.3.217

WRIGHT, K. G. et al. Growth of local food systems: a review of potential food safety implications. CAB Reviews: perspectives in agriculture, veterinary science, nutrition and natural resources, v. 10. https://doi.org/10.1079/ PAVSNNR201410025 